\title{
Richard Turner, O.B.E., M.B., C.M.
}

Richard TURner, son of John Turner of Ratho, Midlothian, was born in 1856 . He was educated at Edinburgh University, where he graduated M.B., C.M., in $188 \mathrm{o}$. His active life as a medical practitioner was spent in York, and in $192 \mathrm{I}$ he retired and settled in Peebles. He died in Edinburgh on April 9, I940.

Dr Turner served for a time as President of the Yorkshire Branch of the British Medical Association, acted as Honorary Consulting Medical Officer of York County Hospital, and during the War of 1914-18 rendered valuable services in military hospitals in York, for which he was awarded the O.B.E. His retiral to Peebles allowed him leisure and scope to follow up his early love for natural history, geology, and archæology. He took a deep interest in the Chambers Institution, rearranging and adding to the exhibited material, and in 1927 published his Descriptive Catalogue of the Geological Collections. This work, which occupied him for several years, is much more than its name implies, for Dr Turner aimed at an individual account of the minerals, rocks, and fossils exhibited, and succeeded in presenting the essential information in a simple and attractive manner. He was drawn also to the study of the remains of early settlements in the Peebles district and carried out, for example, excavations at some of the old hillside terraces at Romanno, Dunsyre, etc. For a number of years he kept daily meteorological records.

In a quiet and unobtrusive way Dr Turner did a great deal to foster in the citizens of Peebles an interest in the natural history and geology of their countryside, and in the classified and augmented collections in the geological museum of the Chambers Institution he has left them a legacy of great and abiding value. He was created a burgess of Peebles in 1923, in recognition of his services to the community.

He was elected a Fellow in 1924.

M. M. 